\title{
Infectrons and coevolution
}

\author{
Infectrons e coevolução
}

\section{Carlos Eduardo Tosta ${ }^{1}$}

Infectious agents are everywhere, in our outer and inner surfaces, in our body fluids, tissues and cells. They dwell the uppermost of our individuality: our genome. Indeed, it has been recognized that about $40 \%$ of mammalian genome is composed of retrotransposons derived from retroviruse ${ }^{1017}$, some integrated to host genome for millions of years ${ }^{12}$. It is proposed that this extensive and prolonged association between humans and microbes generates diversity and mutual adaptation and, consequently, coevolution.

The main instrument of coevolution affecting human and infectious agents is the infectron. This term was coined to encompass the broad array of exogenous DNAs that invade a genome and interfere with its structure or organization, and, therefore, with its function ${ }^{19}$. Infectrons are entire genomes or part of it, have either a short or a lifelong effect on host genome, are originated from any source of DNA, and invade any genome, either by vertical (germline cells) or horizontal (somatic cells) transfer. Insertion of an exogenous DNA into a host genome brings about different outcomes: the alien sequence is rejected, silenced, or retained ${ }^{16}$. Retention, even when temporary, means the ability to trigger insertional mutation or host gene silencing by methylation of cytosines ${ }^{4}$.

Retroelements are the most numerous infectrons integrated into human genome. They arose from retroviruses and are found in three different configurations: as endogenous retroviruses (HERV), which are complete genomes of retroviruses with potential to form new infectious particles, comprising 400 to 500 copies per human haploid genome; as retrotransposons (LINE/L1) that lack the env gene and, consequently, are unable to form new viral particles, although may retrotranspose, with about 100,000 copies per human genome; as retroposons (SINE/Alu), which lack the pol gene that code for the reverse transcriptase and, therefore, do not engage in retrotransposition by their own, and comprise about 500,000 copies per human genome. Although most retroelements are degenerate and inactive sequences resulting from ancient integration, a proportion of them retain the potential to retrotranspose ${ }^{5}$, whereas de novo insertions have been described in association with human disease ${ }^{11}$. In addition, exogenous retroviral
Os agentes infecciosos são encontrados dispersos por todo nosso organismo, estão na pele e mucosas, nos líquidos, tecidos e células. Sua presença é detectada, inclusive, na estrutura que define nossa individualidade: o genoma. De fato, demonstrou-se recentemente que cerca de $40 \%$ de nosso genoma é constituído por retrotransposons derivados de retrovírus ${ }^{10} 17$ alguns integrados ao genoma hospedeiro há milhões de anos ${ }^{12}$. Propõe-se que esta associação extensa e prolongada entre seres humanos e agentes infecciosos seja capaz de gerar diversidade e mútua adaptação e, conseqüentemente, coevolução.

O principal instrumento de coevolução envolvendo o hospedeiro humano e os agentes infecciosos é o infectron. Este termo inclui a grande variedade de ADNs exógenos que podem invadir um genoma e interferir com sua estrutura ou organização e, em conseqüência, com sua função $0^{19}$. Os infectrons são genomas completos ou parte deles, apresentam um efeito transitório ou permanente sobre o genoma hospedeiro, são constituídos por ADN de qualquer fonte, e capaz de invadir qualquer genoma, tanto por transmissão vertical (células da linhagem germinativa), quanto horizontal (células somáticas). A inserção de ADN exógeno no genoma hospedeiro pode resultar em rejeição, silenciamento ou retenção da seqüência exógena ${ }^{16}$. Quando retido, mesmo que de forma transitória, o infectron é capaz de provocar mutação insercional ou silenciamento de genes do genoma hospedeiro por metilação de citosinas ${ }^{4}$.

Os retroelementos constituem os infectrons mais numerosos entre os incorporados ao genoma humano. Eles são originados dos retrovírus e são encontrados em três diferentes configurações: como retrovírus endógenos (HERV: human endogenous retroviruses), que são genomas completos com potencialidade para formar novas partículas infecciosas e compreendem de 400 a 500 cópias por genoma humano haplóide; como retrotransposons (LINE: long interspersed elements/L1), que não expressam o gene env e, em conseqüência, são incapazes de formar novas partículas virais, embora aptos para retrotransposição, com cerca de 100.000 cópias por genoma humano; como retroposons (SINE: short interspersed elements/Alu), não expressam o gene pol que codifica a transcriptase reversa e, assim, não são capazes de apresentar retrotransposição,

\footnotetext{
${ }^{1}$ Laboratórios de Imunologia Celular e de Malária, Faculdade de Medicina, Universidade de Brasília, 70910-900 Brasília, DF, Brasil Recebido para publicação em 19/2/2001.
} 
sequences continue to enter germline cells $s^{8}$, and therefore become endogenized, and vertically transferred to progeny.

An infectious agent can act as an infectron when its genome, or sequences of it, insert into the genome of host cells and disturb its structure or organization, in such way that the function or fate of the cell is altered. Viruses have plenty of opportunities to act as infectrons since they use the replicative apparatus of the host cell for their own replication, and they usually stay for a long while inside the cell. However, the intracellular habitat is not an absolute requisite for an infectious agent to act as an infectron. Indeed, it has been recognized that microbial DNAs circulate freely in the blood ${ }^{18}$, can cross both the cellular ${ }^{7}$ and the nuclear ${ }^{6}$ membranes, gain access to host genome ${ }^{3}$, and become integrated to it ${ }^{4}$. Yet, integration does not appear to be necessary for infectrons interfere with host genomes. Since association of DNA with proteins involves processes that take place on femtosecond $\left(10^{-15} \mathrm{~s}\right)$ or picosecond $\left(10^{-12} \mathrm{~s}\right)$ time scales $^{20}$, it is conceivable that even a short association between infectron and host genome can lead to some functional alteration of the cell.

It is possible that gene changes also occur the other way around, from the host to the infectious agent. An increasing number of microbial proteins, particularly those synthesized by poxviruses and herpesviruses, have been shown to present a high degree of similarity with those of host cells ${ }^{13}$. These proteins include important factors of antiviral defense such as complement components, cytokines, chemokines, and their receptors. This molecular mimicry is considered as part of the survival strategy of viruses ${ }^{14}$, and has been interpreted as due to the capture of host genes by the virus ${ }^{215}$. However, the possibility that this similarity between human and viral proteins is due to the capture of viral genes by human genome cannot be ruled out.

Infectronic changes among infectious agents and the host lead to diversity and, hence, to adaptability. Since they may exhibit a bi-directional nature, they bring about mutual adaptation and coevolution. This proposal is consistent with the recognition that genomes are dynamic structures that learn as they move through time and generations, and can take up from the outside information that transform their behavior in a heritable way ${ }^{1}$. compreendem cerca de 500.000 cópias por genoma humano. Embora a maioria dos retroelementos seja formada por seqüências degeneradas e inativas, resultantes de antigas integrações ao genoma, uma proporção daqueles que expressam o gene da transcriptase reversa retêm a potencialidade para retrotransposição ${ }^{5}$. Tem sido descrita a ocorrência de novas inserções, em associação com doenças humanas ${ }^{11}$, além de integração de retrovírus exógenos em células da linhagem germinativa ${ }^{8}$, tornando-se assim endogenizados e passíveis de transmissão vertical para a progênie.

Um agente infeccioso pode agir como infectron quando seu genoma, ou seqüências dele, insere-se no genoma da célula hospedeira e interfere com sua estrutura ou organização, de maneira a alterar a função ou o destino da célula. Os vírus têm amplas oportunidades para atuar como infectrons já que eles apresentam íntima associação com o genoma hospedeiro, além de geralmente infectar a célula por tempo prolongado. Entretanto, o habitat intracelular não representa um requisito para que um agente infeccioso atue como infectron. De fato, tem sido demonstrado que ADNs de diferentes agentes infecciosos circulam livremente no sangue $^{18}$, podem atravessar tanto a membrana celular ${ }^{7}$ como a nuclear ${ }^{6}$, alcançam o genoma hospedeiro ${ }^{3}$, e são capazes de a ele se integrar ${ }^{4}$. Contudo, a integração não parece ser um requisito necessário para que o infectron interfira com o genoma hospedeiro já que fenômenos de associação de ADN com proteínas podem ocorrer na escala de picossegundos $\left(10^{-12} \mathrm{~s}\right)$ até de femtossegundos $\left(10^{-15} \mathrm{~s}\right)^{20}$, é possível que mesmo uma curta associação entre o infectron e o genoma hospedeiro possa causar alterações funcionais na célula.

É possível que trocas gênicas também ocorram no sentido do hospedeiro para o agente infeccioso. Tem sido demonstrado que um crescente número de proteínas microbianas, particularmente as sintetizadas por poxvírus e herpesvírus, apresentam um alto grau de similaridade com as do hospedeiro ${ }^{13}$. Estas proteínas incluem importantes fatores de defesa antiviral como componentes do complemento, citocinas, quimiocinas e seus receptores. Este mimetismo molecular é considerado como parte da estratégia de sobrevivência dos vírus ${ }^{14}$, e tem sido interpretado como devido à captura de genes do hospedeiro pelo agente infeccioso ${ }^{215}$. Entretanto, a possibilidade de que a similaridade entre proteínas decorra da captura de genes de agentes infecciosos pelo genoma humano não pode ser descartada.

As trocas infectrônicas entre agentes infecciosos e o hospedeiro leva à diversidade gênica e, em conseqüência, à adaptabilidade. Considerando que as trocas podem ser bidirecionais, são capazes de ocasionar mútua adaptação e coevolução. Esta proposta é consistente com o reconhecimento de que os genomas são estruturas dinâmicas que incorporam características à medida que se movem através do tempo e das gerações e que são suscetíveis de captar do exterior informações que transformam seu comportamento em característica herdável' ${ }^{1}$. 


\section{REFERENCES}

1. Caporale LH. Chance favors the prepared genome. Annals of the New York Academy of Sciences 870:1-21, 1999.

2. Cohen JI. The biology of Epstein-Barr virus: lessons learned from the virus and the host. Current Opinion on Immunology 11:365370, 1999.

3. Doerfler W. The insertion of foreign DNA into mammalian genomes and its consequences: a concept in oncogenesis. Advances in Cancer Research 66:313-344, 1995.

4. Doerfler W, Schubbert R, Heller H, Kammer C, Hilger-Eversheim $\mathrm{K}$, Knoblauch M, Remus R. Integration of foreign DNA and its consequences in mammalian systems. Trends in Biotechnology 15:297-301, 1997

5. Esnault C, Maestre J, Heidmann T. Human LINE retrotransposons generate processed pseudogenes. Nature Genetics 24:363-367, 2000.

6. Gerace L. Molecular trafficking across the nuclear pore complex. Current Opinion in Cell Biology 4:637-645, 1992.

7. Hefeneider SH, Cornell KA, Brown LE, Bakke AC, McCoy SL, Bennett RM. Nucleosomes and DNA bind to specific cell-surface molecules on murine cells and induce cytokine production. Clinical Immunology and Immunopathology 63:245-251, 1992.

8. Katz RA, Skalka AM. Generation of diversity in retroviruses. Annual Review of Genetics 24: 409-445, 1990.

9. Kazazian HH Jr. Mobile elements and disease. Current Opinion in Genetics and Development 8:343-350, 1998.

10. Kazazian HH Jr. L1 retrotransposons shape the mammalian genome. Science 289:1152-1153, 2000.

11. Kazazian HH Jr, Wong C, Youssoufian H, Scott AF, Phillips DG, Antonarakis SE. Haemophilia A resulting from de novo insertion of $L 1$ sequences represents a novel mechanism for mutation in man. Nature 332:164-166, 1988.

12. Kim HS, Takenaka O, Crow TJ. Isolation and phylogeny of endogenous retrovirus sequences belonging to the HERV-W family in primates. Journal of General Virology 80:2613-2619, 1999.

13. Lalani AS, Barrett JW, McFadden G. Modulating chemokines: more lessons from viruses. Immunology Today 21:100-106, 2000.

14. McFadden G, Murphy PM. Host-related immunomodulators encoded by poxviruses and herpesviruses. Current Opinion in Microbiology 3:371-378, 2000.

15. Murphy PM. Molecular piracy of chemokine receptors by herpesviruses. Infectious Agents and Disease 3:137-154, 1994.

16. Scrable $\mathrm{H}$, Stambrook PJ. A genetic program for deletion of foreign DNA from the mammalian genome. Mutation Research 429: 225237, 1999.

17. Smit AF. Interspersed repeats and other mementos of transposable elements in mammalian genomes. Current Opinion in Genetics and Development 9:657-663, 1999.

18. Stroun M, Maurice P, Vassioukhin V, Lyautey J, Lederrey C, Lefort F, Rossier A, Chen XQ, Anker P. The origin and mechanism of circulating DNA. Annals of the New York Academy of Sciences 906:161-168, 2000.

19. Tosta CE. Coevolutionary networks: a novel approach to understanding the relationships of humans with the infectious agents. Memórias do Instituto Oswaldo Cruz (no prelo).

20. Wan C, Fiebig T, Kelley SO, Treadway CR, Barton JK, Zewail AH. Femtosecond dynamics of DNA-mediated electron transfer. Proceedings of the National Academy of Sciences USA 96:60146019 , 